\title{
ТЕОРЕТИКО-МЕТОДОЛОГІЧНІ ТА ПРИКЛАДНІ ЗАСАДИ РОЗВИТКУ ОБДАРОВАНОЇ ОСОБИСТОСТІ
}

\author{
Наукова доповідь на методологічному семінарі НАПН України «Розвиток \\ обдарованої особистості: світовий та вітчизняний контексти»
}

18 лucmonada 2021 p.

https://doi.org/10.37472/2707-305X-2021-3-2-13-1

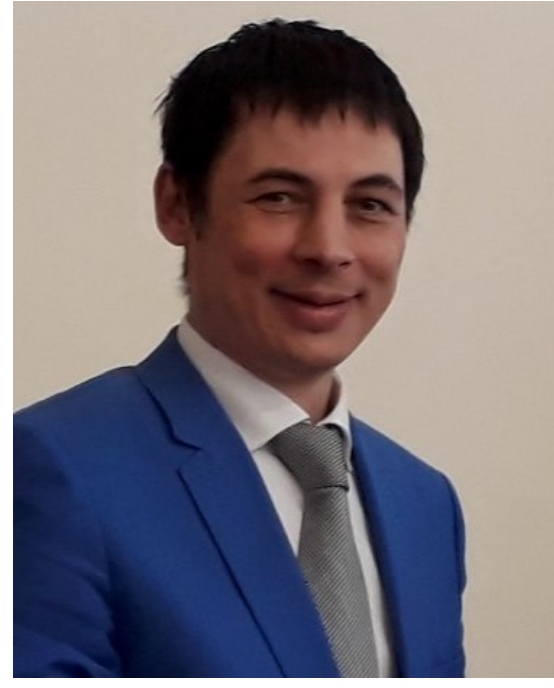

ГАЛЬЧЕНКО

Максим Сергійович

доктор філософських наук,

директор Iнституmy

обдарованої дитини

Начіональної академії

педагогічних наук України, м. Київ, Україна
Анотація. Цивілізаційний поступ людства переконливо засвідчує, що обдаровані особистості генерують левову частку світових інновачій та є рушійною силою стійкого розвитку людського капіталу, світової економіки і науки. Відповідно розвиток обдарованих особистостей $\epsilon$ пріоритетним завданням країни. В Інституті обдарованої дитини НАПН України досліджують феномен обдарованості, здійснюють методичне забезпечення діагностики обдарованості та розвитку їі структурних складників, створюють програми й методики розвитку обдарованої особистості на різних вікових етаnах, розробляють теоретико-методичні засади спеціалізованої освіти наукового спрямування тощо. Учені Інституту запропонували новий підхід до розуміння обдарованості як єдності розумової, духовної та фрізичноі срер особистості. Також розроблено оригінальні та адаптовано зарубіжні методики виявлення обдарованості в учнів, створено профорієнтаційно-діагностичну тестову систему. Встановлено, що формування в учнів умінь отримання знань $з$ використанням дослідницьких методів є найбільш ефективним фрактором розвитку тих складників обдарованості, які підпадають під педагогічний вплив. Як наслідок, вчені Інституту сприяють імплементації в освітній простір України парадигми наукової освіти та концепції спеціалізованої освіти наукового спрямування.

Ключові слова: Інститут обдарованої дитини НАПН України; обдарованість; розвиток; діагностика обдарованості; наукова освіта; спеціалізована освіта наукового спрямування.

Цивілізаційний поступ людства переконливо засвідчує, що обдаровані особистості генерують левову частку світових інновацій та $€$ рушійною силою стійкого розвитку людського капіталу, світової економіки й науки. Інновації, створені ними, не лише кардинально впливають на наукову, технологічну та економічну сфери, а й видозмінюють традиційні соціальні та культурні процеси. Закономірно, що це безпосередньо позначається як на темпах інноваційного розвитку людства, так і на якості та змісті життя кожного індивіда. Як наслідок, якісна освіта обдарованих дітей та молоді є одним 3 пріоритетів освітньої політики цивілізованих країн і України зокрема. Адже конкурентоспроможність будь-якої держави на глобальних світових ринках, добробут її громадян безпосередньо пов'язані з формуванням і освітою інтелектуальної еліти.

Пріоритети вітчизняної політики у сфері обдарованості актуалізовано чинним законодавством та нормативно-правовими актами (Закон України «Про освіту»; Стандарт спеціалізованої освіти нау- 
кового спрямування, затверджений наказом МОН України від 16 жовтня 2019 р. № 1303; Положення про науковий ліцей, затверджене постановою Кабінету Міністрів України від 22 травня 2019 р. № 438), що унормовують правове підґрунтя освіти та підтримки обдарованих дітей, окреслюють напрями реформування освітньої системи в контексті розвитку структурних складників обдарованості.

у межах освітніх реформ, що відбуваються протягом останніх років, розширюється освітній простір, а саме мережа закладів, де можуть навчатися обдаровані діти. Простежується збільшення кількості гімназій та ліцеїв, а також розширення мережі зазначених закладів освіти у сільських поселеннях. Зокрема кількість гімназій 3 499 одиниць (2,9% від загальної кількості закладів загальної середньої освіти у 2014/15 навчальному році) у 2019/20 навчальному році збільшилася на 155 (4,3 \% від загальної кількості закладів загальної середньої освіти). Якщо у 2014/15 навчальному році функціонувало 324 ліцеї (1,9% від загальної кількості закладів загальної середньої освіти), то в 2019/20 навчальному році їх налічувалося 870 (5,8 \% від загальної кількості). Загалом у цих закладах освіти у 2019/20 навчальному році навчалося $16 \%$ від загальної кількості учнів (Аніщенко та ін., 2021).

За останнє десятиліття спостерігається підвищення суспільного інтересу до обдарованості та обдарованих у світі й Україні. Найперше, це світова тенденція орієнтації на оригінальність та унікальність. У вітчизняних реаліях підвищення соціального запиту на освіту й розвиток обдарованих дітей можна констатувати за рівнем затребуваності альтернативних послуг, що представлені на ринку, коли батьки умотивовано підтримують індивідуальну освітню траєкторію розвитку своїх дітей. Тобто батьки, визначаючи певні природні здібності своїх дітей, які проявляються в освітньому процесі, шукають можливості та інструменти для їх подальшого розвитку. Все це увиразнює широке проблемне поле у сфері обдарованості, яке є предметом наукового інтересу вчених Інституту обдарованої дитини Національної академії педагогічних наук України.

В Інституті обдарованої дитини НАПН України науковці досліджують феномен обдарованості, здійснюють методичне забезпечення діагностики обдарованості та розвитку ії структурних складників, створюють програми й методики розвитку обдарованої особистості на різних вікових етапах, розробляють теоретико-методичні засади спеціалізованої освіти наукового спрямування тощо.

Наукові дослідження, що їх проводять учені Інституту обдарованої дитини НАПН України, засвідчують, що актуальними фундаментальними проблемами, які потребують швидкого реагування, $€$ :

- теоретико-методологічні розбіжності визначення феномену обдарованості;

- відсутність цілісної методики діагностики обдарованості (більшість наявних методик діагностування спрямовані на окремі прояви інтелекту (IQ));

- потреба впровадження інноваційних підходів до навчання обдарованих учнів як у формальному, так і в неформальному та інформальному сегментах.

Людство впродовж десятиліть намагається з'ясувати причину того, чому одні особистості залишають після себе помітний трек у житті, а інші відходять зовсім непомітними, деякі особистості у дитячі роки вражають своїми здібностями, але у зрілому віці не досягають значних здобутків, у той час як інші у дитячому віці не привертають до себе увагу, зате у зрілому віці досягають значних висот. Щоб пояснити перше, необхідно пов'язати життєвий успіх особистості з ії інтелектом. Щоб пояснити друге, високий інтелект необхідно доповнити особистісними якостями індивіда. Щоб пояснити третє, потрібно збагнути, що в основі інтелекту особистості міститься стиль ії пізнавальної та творчої діяльності. Якщо зазначене вище доповнити здатністю направити в потрібний час у потрібне місце необхідну кількість енергії, то приходимо до трактування обдарованості як єдності розумової, духовної та фізичної сфер індивіда.

Діяльність учених Інституту обдарованої дитини НАПН України фокусується на розв'язанні зазначеної проблеми. Зокрема в Інституті розроблено інноваційний підхід до трактування інтелекту як апарату розумної поведінки індивіда. Розумна поведінка визначається тим, як індивід накопичує життєвий досвід і використовує його у проблемних ситуаціях. Якщо конкретніше, то розумна поведінка визначається стилем накопичення життєвого досвіду. Розумної поведінки слід очікувати від того індивіда, який накопичує життєвий досвід у такій формі, яка у випадку проблемної ситуації дає йому змогу позбутися засвоєних стереотипів. Серед структурних компонентів інтелекту виокремлено пізнавальний і креативний блоки. Очікується, що дослідження пізнавального і креа- 
тивного блоків інтелекту разом із даними спостережень педагогів дасть набагато більше інформації про його рівень, аніж використання традиційних тестів інтелекту і креативності чи навіть їх поєднання.

3 наведеного вище видно, що в Інституті запропоновано враховувати морально-вольові, емоційні та енергетичні складники обдарованості. Створена на цій основі методика уможливить здійснення більш достовірної діагностики обдарованості особистості і вироблення відповідної стратегії і тактики ефективного розвитку ії структурних складників.

Виходячи з теоретичних позицій трактування обдарованості та методологічних підвалин ії̈ діагностики, в Інституті розробляють методики діагностики різних типів спеціальної обдарованості.

Оригінальною, наприклад, $є$ методика діагностики особистісних чинників розвитку інтелектуальної обдарованості. Саме вона уможливлює здійснення достовірної попередньої прогностичної оцінки інтелектуальної обдарованості особистості і вироблення відповідної стратегії і тактики ії ефективного розвитку. Інноваційною є методика діагностики практичного інтелекту учнівської молоді, яка побудована на засадах середовищного і проєктного підходів.

Учені Інституту встановили, що інтелектуально обдаровані старшокласники демонструють більш високу надситуативну активність. Таким учням притаманні відкритість досвіду, допитливість, готовність до експериментування, висока пізнавальна активність, здоровий перфекціонізм, захопленість під час вирішення складних завдань.

Вони демонструють значущо більшу творчу результативність, мають адекватну самооцінку, відзначаються особистісною незалежністю (неконформністю), рішучістю, ініціативністю, наполегливістю у досягненні мети, схильністю до ризику, толерантністю до невизначеності, самодостатністю, прагненням керуватися власною системою критеріїв оцінки. Їм властиві самоприйняття та самоповага, відчуття своєї цінності, спонтанність у проявах почуттів та думок, прагнення до особистої та творчої самореалізації.

Доведено, що інтелектуально обдаровані старшокласники більшою мірою, порівняно з учнівським загалом, у ситуації вибору (прийняття рішення) схильні спиратися на міркування раціональнологічного характеру, факти і здоровий глузд.

Крім того, в Інституті адаптовано та апробовано низку діагностичних методик. Ідеться про тест
«Типи креативності» К. Венкера; модифіковані тести креативності Р. Вільямса; тест розумового розвитку для абітурієнтів та старшокласників (АСТУР); тест емоційної спрямованості Б. Додонова; методику вивчення естетичної обдарованості «Мистецтвознавець»; тест структури інтелекту Р. Амтхауера; методику діагностики особистісних факторів розвитку складників обдарованості; експертну оцінювальну анкету для визначення учнів з ознаками інтелектуальної та академічної обдарованості та ін.

Створено профорієнтаційно-діагностичну тестову систему «Інтереси та здібності». Система спрямована на двостороннє дослідження особистості, а саме: мотиваційної структури (професійних інтересів, схильностей) та структури здібностей, що дає змогу здійснювати прогнозування навчальної та професійної успішності особистості в різних сферах діяльності. Зазначене є важливим елементом системи психолого-педагогічної підтримки обдарованих, розвитку складників обдарованості та фактором своєчасного й успішного самовизначення щодо майбутньої професії обдарованих учнів, оскільки забезпечує заклади освіти необхідною інформацією для побудови індивідуальних траєкторій розвитку обдарованої особистості.

Для полегшення інструментального застосування діагностик обдарованості здійснено їх цифровізацію та створено цифровий програмний комплекс, що дає змогу здійснювати онлайндіагностику учнівської молоді з метою виявлення типів обдарованості.

Аналіз результатів досліджень засвідчив, що формування в учнів умінь отримання знань з використанням дослідницьких методів $€$ найбільш ефективним фактором розвитку тих складників обдарованості, які підпадають під педагогічний вплив. Як наслідок, учені Інституту сприяють імплементації в освітній простір України парадигми наукової освіти та концепції спеціалізованої освіти наукового спрямування.

Освіта наукового спрямування - це вид спеціалізованої освіти, що базується на дослідноорієнтованому навчанні, спрямованому на поглиблене вивчення профільних предметів та набуття компетентностей, необхідних для подальшої дослідно-експериментальної, конструкторської, винахідницької діяльності. Здобувається ця освіта на базовому і профільному рівнях (Закон України «Про освіту», 2017). 
У межах цього напряму вчені Інституту створили «Проєкт освітньої програми для закладів спеціалізованої освіти наукового спрямування» (Поліхун та ін., 2021). Запропонований проєкт складається із цільового, змістового, організаційного та оцінювального блоків, у яких подано загальну характеристику та особливості освітньої програми СОНС, перелік суб'єктів освітньої діяльності, які долучаються до створення і реалізації освітньої програми; сформульовано ії мету і завдання, визначено вимоги до осіб, які можуть розпочати навчання за програмою, вимоги до обов'язкових результатів навчання здобувачів освіти, формування їхніх дослідницьких компетентностей та обов'язкових результатів навчання відповідно до етапів дослідницької, конструкторської, винахідницької діяльності, опис та рекомендовані інструменти системи внутрішнього забезпечення якості освіти.

Інститут спільно з Малою академією наук України та за науково-методичної підтримки фахівців Музею Ханенків розпочав роботу над пілотною програмою наукової освіти для школярів «STEAMуроки в Музеї Ханенків».

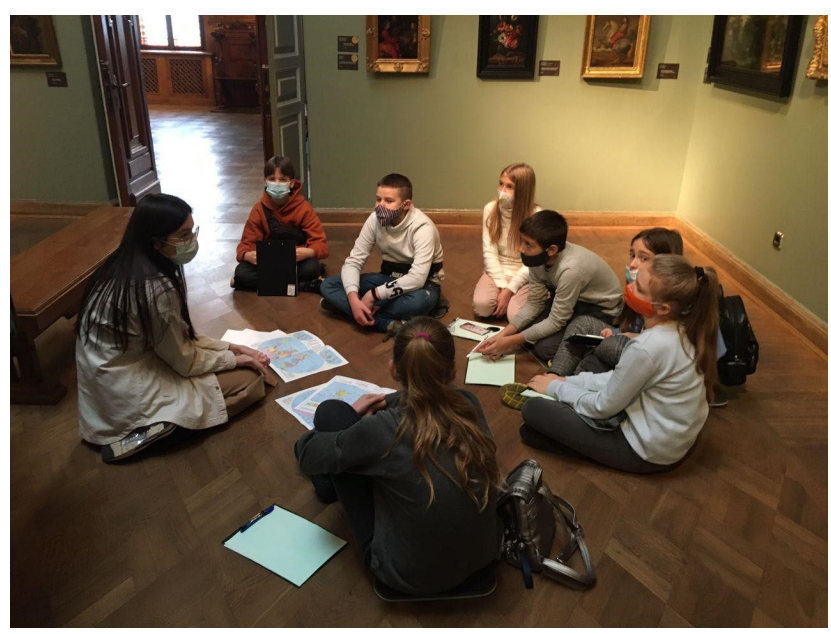

Цей освітній продукт поєднує в собі матеріал кількох освітніх галузей з можливістю його фахового представлення через долучення до творів мистецтва, предметів побуту й культури, які ретельно добирають фахівці музею. Дизайн програми сформовано на основі логічного представлення обраної шкільної теми та організації інтерактивного навчального процесу «відкриття через дослідження», що його здійснює сама дитина в залах музею. Наразі ключовим завданням програми наукової освіти «STEAM-уроки в Музеї Ханенків» $\epsilon$ апробація реальних шляхів інтеграції формальної та неформальної освіти, а відтак і впрова- дження найкращих практик сучасної музейної педагогіки в навчальний процес закладів формальної освіти - поки що на рівні «вільного практикуму», який допомагає в освоєнні програмного матеріалу основної школи та не є обов'язковим.

Однак у перспективі міждисциплінарний творчий простір Музею Ханенків, як і будь-якого іншого музею, може стати інноваційним, інтегрованим у навчальний процес складником, зокрема в закладах спеціалізованої освіти наукового спрямування. Історичний і мистецький складники освітнього простору музею є тим сприятливим середовищем, яке налаштовує на продуктивне міждисциплінарне спілкування, виконує функцію об'єднання та інтеграції всіх учасників програми, дає змогу виявити творчі здібності та ціннісні орієнтації, актуалізувати знання та набутий досвід, оскільки складниками програми є творчі, пошукові завдання для групової взаємодії, наприклад, мініпроєкт з вирішення реальної проблеми певного регіону тощо.

Перспективами подальших досліджень $€$ вивчення чинників розвитку складників обдарованої особистості залежно від типу обдарованості. На наше переконання, це сприятиме вдосконаленню психолого-педагогічного супроводу розвитку обдарованих, ефективній реалізації індивідуальної освітньої траєкторії обдарованих учнів, підвищенню рівня науково-методичного забезпечення педагогічних працівників закладів освіти, що працюють з обдарованими дітьми та молоддю.

Водночас наріжним каменем нашої роботи $є$ і залишається перспектива розроблення валідної і надійної методики діагностики обдарованості (у традиційній термінології - загальної обдарованості), що є фундаментом для різних типів спеціальної обдарованості. І якщо навіть не вести мову про віддалену перспективу соціально-економічного виміру позитивного вирішення цього завдання, то актуальність його не слабшає, якщо взяти до уваги, що ідентифікація обдарованих $€$ необхідною складовою частиною освітнього процесу, оскільки їхній потенціал не розвивається ефективно і навіть пригнічується в умовах масової уніфікованої освіти, яка не відповідає специфіці засвоєння ними знань та потребі їх творчого використання.

\section{СПИСОК ВИКОРИСТАНИХ ДЖЕРЕЛ}

Аніщенко, О.В., Базелюк, Н.В., Березівська, Л.Д., Бех, І.Д., Биков, В.Ю., Бойко, А.Е., Вашуленко, О.П., Вербицький, В.В., Вітренко, Ю.М., Ворона, В.О., Гавриш, Н.В., Гальченко, М.С., Гордієнко, В.П., Гудим, І.М., Джурило, А.П., Довбищенко, В.І., Драч, І.І., 
Єршова, Л.М., Жиляєв, І.Б., ... Ярошенко, О.Г. (2021). Національна доповідь про стан і перспективи розвитку освіти в Україні (До 30-річчя незалежності України) : монографія (В.Г. Кремень, ред.). Національна академія педагогічних наук України. Київ: КОНВІ ПРІНТ. https:// doi.org/10.37472/NAES-2021-ua

Закон України «Про освіту». (2017, 5 вересня). https:// zakon.rada.gov.ua/laws/show/2145-19

Інститут обдарованої дитини НАПН України. (2021, 22 листопада). Методологічний семінар «Розвиток обдарованої особистості: світовий та вітчизняний контексти». https://www.iod.gov.ua/articles.php? article_id $=37$
Кабінет Міністрів України. (2019, 22 травня). Про затвердження Положення про науковий ліщей (438). https://zakon.rada.gov.ua/laws/show/438-2019-п

Міністерство освіти і науки України. (2019, 16 жовтня). Про затвердження Стандарту спеціалізованої освіти наукового спрямування (1303). https:// mon.gov.ua/ua/npa/pro-zatverdzhennya-standartuspecializovanoyi-osviti-naukovogo-spryamuvannya

Поліхун, Н.І., Постова, К.Г., Сліпухіна, І.А., \& Горбань, Л.В. (2021). Проєкт освітньої програми для закладів спеціалізованої освіти наукового спрямування. Київ: Інститут обдарованої дитини НАПН України. https://lib.iitta.gov.ua/726216/

\title{
THEORETICAL, METHODOLOGICAL, AND APPLIED PRINCIPLES OF THE GIFTED PERSONALITY DEVELOPMENT \\ Scientific report at the methodological seminar of the National Academy of Educational Sciences of Ukraine "Gifted Personality Development: World and Ukrainian Contexts", November 18, 2021
}

\author{
Maksym Halchenko \\ DSc in Philosophy, Director, Institute of the Gifted Child of the National \\ Academy of Educational Sciences of Ukraine, Kyiv, Ukraine
}

Abstract. The civilizational progress of humankind convincingly proves that the gifted individuals generate the bulk
of world innovations and are the driving force of sustainable development of human capital, the world economy, and
science. Accordingly, the development of gifted individuals is a priority for the country. The Institute of the Gifted Child
of the National Academy of Educational Sciences of Ukraine studies the phenomenon of giftedness, provides
methodological support for the diagnostics of giftedness and development of its structural components, creates
programs and methods of the gifted personality development at different ages, develops theoretical and
methodological principles of specialized scientific education. The institute's researchers have proposed a new approach
to understanding giftedness as a unity of personality's mental, spiritual, and physical spheres. The institute created
original and adapted foreign methods of identification of giftedness in students, as well as a career guidance diagnostic
test system. It is established that the development of students' skills to acquire knowledge using research methods is
the most influential factor in developing those components of giftedness that are subject to pedagogical influence. As a
result, the institute's researchers promote the implementation of the paradigm of scientific education and the concept
of specialized scientific education in the educational space of Ukraine.
Keywords: Institute of the Gifted Child of NAES of Ukraine; giftedness; development; giftedness diagnostics; scientific education; specialized scientific education. 